\title{
Spectroscopic properties of halite from Kłodawa salt mine, central Poland
}

\author{
Sylwia M. Zelek • Aleksandra Weselucha-Birczyńska • \\ Janusz Szklarzewicz • Katarzyna M. Stadnicka
}

Received: 26 February 2014 / Accepted: 8 August 2014 / Published online: 20 August 2014

(C) The Author(s) 2014. This article is published with open access at Springerlink.com

\begin{abstract}
The dynamics of colour centre transformation was investigated in blue halite single crystals from Kłodawa Salt Mine, Central Poland, using UV-vis spectroscopy. The following colour centres were considered: $F, R_{1}, R_{2}$, as well as plasmons and $M$ centres. The $R_{2}$ centres predominated in navy blue (A) and pale blue (B) halites. Other relatively large populations were plasmons found in all examined samples. In purple (C) halite samples the plasmon population is the highest one among others and $R_{1}$ centres appeared to be equally significant, whereas $M$ centres were almost absent. For $\mathrm{A}$ and $\mathrm{C}$ samples unidentified bands were observed at 26,500 to $26,200 \mathrm{~cm}^{-1}$, respectively. The bleaching process of the blue halites was investigated using temperature dependent UV-vis and micro-Raman spectroscopies. In micro-Raman $300-100 \mathrm{~cm}^{-1}$ region three very intense sharp bands were attributed to the colour centres and colloidal $\mathrm{Na}$ precipitation in A and B halites. The one broad band in the range 3,500 to $500 \mathrm{~cm}^{-1}$, which was characteristic even for the colourless sample $\mathrm{D}$ but absent in the spectra of colourless $\mathrm{NaCl}$ obtained after recrystallization of sample A, requires further study.
\end{abstract}

\section{Introduction}

The occurrence of natural blue or purple crystals of halite has been the subject of interest for many scientists. The early

Editorial handling: L. Nasdala

S. M. Zelek $(\bowtie)$

Faculty of Geology, Geophysics and Environmental Protection, AGH University of Science and Technology, al. Mickiewicza 30, 30-059 Kraków, Poland

e-mail: zelek@geol.agh.edu.pl

A. Wesełucha-Birczyńska • J. Szklarzewicz $\cdot$ K. M. Stadnicka Faculty of Chemistry, Jagiellonian University, ul. R. Ingardena 3, 30-060 Kraków, Poland works on this topic are dated on the second half of 19 th century. From among numerous works of 20th century the publication by Howard and Kerr (1960), a series of four papers on radiation damage in $\mathrm{NaCl}$ by Weerkamp et al. (1994), Seinen et al. (1994a,b), and Groote et al. (1994), as well as a review article by Sonnenfeld (1995) should be emphasized. Recently some examples of naturally occurring variety of colour centres in $\mathrm{NaCl}$ crystals from Kłodawa Salt Mine were identified by Wesełucha-Birczyńska et al. (2012). Interest in halite appeared again in connection with microbial life found in hypersaline environments such as those present on early Mars according to the research conducted by NASA's astrobiology program (AzuaBustos et al. 2012; Edwards et al. 2006).

The present paper is one of an article series devoted to halites from Kłodawa Salt Mine. UV-vis spectroscopy was used for detection of colour centres in blue halite single crystals and their bleaching under heating. It concerns the spectroscopic properties of blue halite whereas the previous one dealt with lattice deformation of blue halites, their chemical composition, optical properties and solid state inclusions (Zelek et al. 2014).

\section{Samples and experiments}

Geological setting - origin of minerals and sample description

The occurrence of blue and purple forms of halite associated with potassium minerals typical for Zechstein salt formations were found in Kłodawa salt dome belonging to the Polish Zechstein Basin. The halite beds are accompanied by sylvinite veins (Natkaniec-Nowak and Toboła 2003; Toboła et al. 2007; Janiów et al. 2008; Wesełucha-Birczyńska et al. 2008) with the high 
Fig. 1 The representative UVvis spectra for navy blue (a), pale blue (b), purple (C) and colourless (d) halite samples from Kłodawa Salt Mine. Band components are described by the numbers according to Table 1 . Note different scale for absorbance values in each case
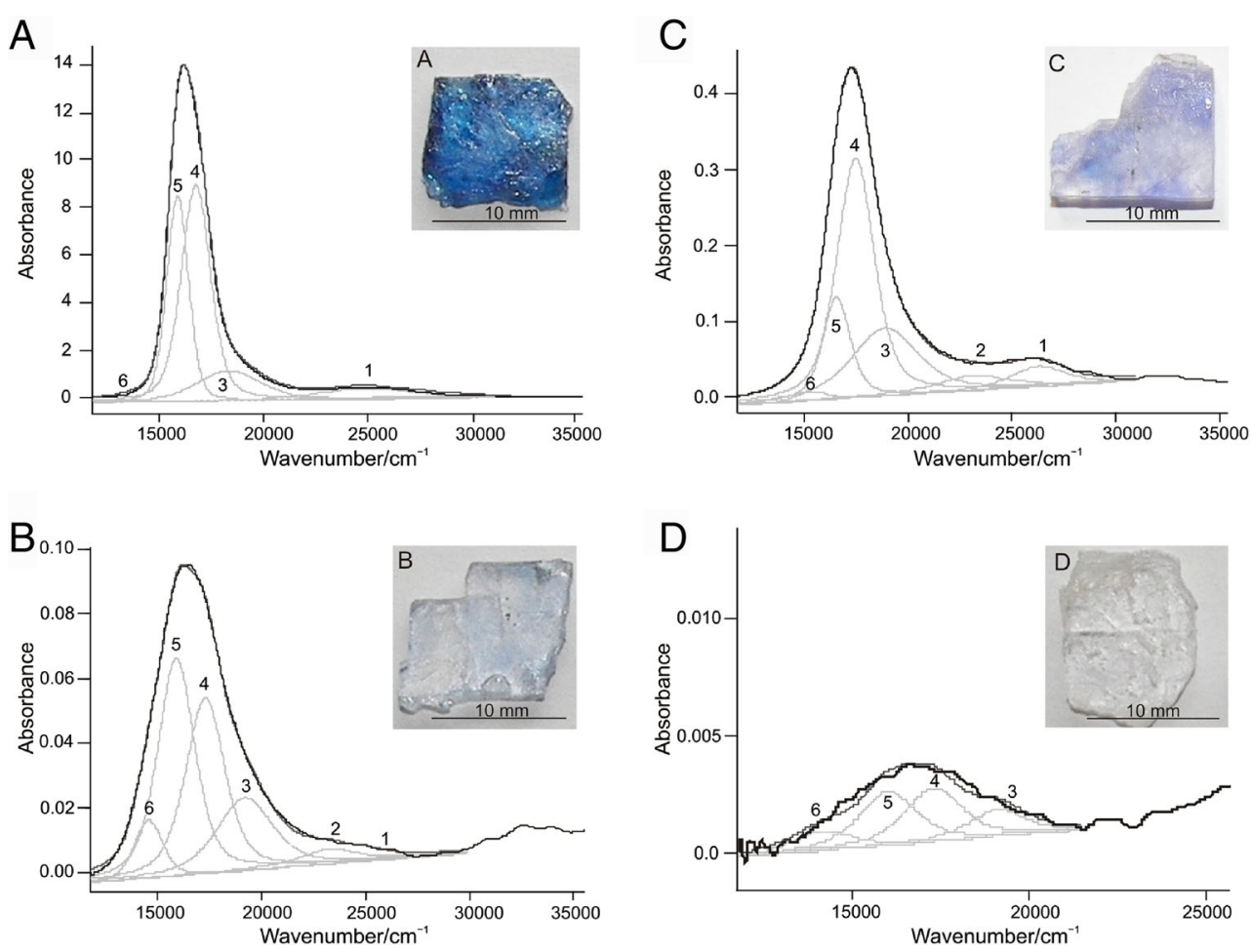

contents of potassium-40 (Zelek 2012; Zelek et al. 2014). The potassium isotope could be considered as the source of radiation necessary for the production of scattered F-centres. All single crystals used in the research (A, B, C and D types) were taken from the blue halite outcrops localized in the ventilating gallery between chambers KS39 and KS38 (on the level $562 \mathrm{~m}$ ).
The single crystals samples were prepared using cleavage properties of halite and the measured surfaces were not actually modified by grinding and polishing. In ambient conditions the single crystals of halites were relatively stable. Selected fragments were isolated from the rock according to colouration which was defined using UV-vis spectra and assigned the following sym-

Table 1 Description of UV-vis absorption bands: experimental band positions $\left(\mathrm{cm}^{-1}\right)$, FWHM $\left(\mathrm{cm}^{-1}\right), \mathrm{N}_{\mathrm{F}}$ population according to WesełuchaBirczyńska et al. (2012)

\begin{tabular}{|c|c|c|c|c|c|c|c|c|}
\hline \multirow[t]{2}{*}{ Sample } & \multirow[t]{2}{*}{ Distance $\mathrm{Na}-\mathrm{Na} / \AA$ (Zelek 2012) } & \multicolumn{7}{|c|}{ Position of absorption band $/ \mathrm{cm}^{-1}$} \\
\hline & & & $\begin{array}{l}1 \\
\text { Unidentifiedband }\end{array}$ & $\begin{array}{l}2 \\
F \text { band }\end{array}$ & $\begin{array}{l}3 \\
\mathrm{R}_{1}\left(\mathrm{~F}_{3}\right) \text { band }\end{array}$ & $\begin{array}{l}4 \\
\mathrm{R}_{2}\left(\mathrm{~F}_{3}\right) \text { band }\end{array}$ & $\begin{array}{l}5 \\
\text { Plasmon band }\end{array}$ & $\begin{array}{l}6 \\
\mathrm{M}\left(\mathrm{F}_{2}\right) \text { band }\end{array}$ \\
\hline \multirow[t]{3}{*}{ A } & \multirow[t]{3}{*}{$2.8185(2)$} & $\lambda_{\exp }$ & 24,900 & - & 18,300 & 16,800 & 15,900 & 14,200 \\
\hline & & FWHM & 6,000 & - & 3,600 & 1,700 & 1,200 & 100 \\
\hline & & Population $\mathrm{N}_{\mathrm{F}}$ & $1.23 \times 10^{16}$ & - & $2.11 \times 10^{16}$ & $7.21 \times 10^{16}$ & $5.12 \times 10^{16}$ & $9.71 \times 10^{12}$ \\
\hline \multirow[t]{3}{*}{ B } & \multirow[t]{3}{*}{$2.8191(1)$} & $\lambda_{\exp }$ & 25,200 & 23,200 & 19,200 & 17,300 & 15,900 & 14,600 \\
\hline & & FWHM & 1,200 & 3,500 & 3,200 & 2,200 & 2,100 & 1,600 \\
\hline & & Population $\mathrm{N}_{\mathrm{F}}$ & $6.45 \times 10^{12}$ & $1.07 \times 10^{14}$ & $4.88 \times 10^{14}$ & $8.31 \times 10^{14}$ & $9.69 \times 10^{14}$ & $1.94 \times 10^{14}$ \\
\hline \multirow[t]{3}{*}{$\mathrm{C}$} & \multirow[t]{3}{*}{$2.8207(1)$} & $\lambda_{\exp }$ & 26,300 & 23,100 & 18,900 & 17,500 & 16,600 & 15,400 \\
\hline & & FWHM & 3,100 & 4,100 & 3,800 & 2,100 & 1,600 & 1,800 \\
\hline & & Population $\mathrm{N}_{\mathrm{F}}$ & $1.31 \times 10^{13}$ & $1.01 \times 10^{14}$ & $4.78 \times 10^{14}$ & $6.50 \times 10^{14}$ & $5.91 \times 10^{14}$ & $1.82 \times 10^{14}$ \\
\hline \multirow[t]{3}{*}{$\mathrm{D}$} & \multirow[t]{3}{*}{$2.8208(1)$} & $\lambda_{\exp }$ & - & - & 19,100 & 17,300 & 16,000 & 14,200 \\
\hline & & FWHM & - & - & 1,900 & 1,900 & 1,900 & 1,900 \\
\hline & & Population $\mathrm{N}_{\mathrm{F}}$ & - & - & $9.98 \times 10^{12}$ & $1.98 \times 10^{13}$ & $1.97 \times 10^{13}$ & $7.07 \times 10^{12}$ \\
\hline
\end{tabular}

Estimated standard deviations of band positions are in the range $70-200 \mathrm{~cm}^{-1}$ and those of FWHM: $70-130 \mathrm{~cm}^{-1}$ for well defined maxima 
bols: A - navy blue, B - pale blue, C - purple and D natural colourless fragments of rock salt (shown in Fig. 1 as insets). The saturation of blue hue in the halite aggregates was not homogeneous (compare Fig. 1 and examples in Zelek et al. 2014). These crystals displayed zones of navy blue hue, pale blue or purple hue alternate with colourless ones.

\section{Methods}

The UV-vis spectra for halite crystals of A, B, C and colourless D from Kłodawa Salt Mine were recorded on spectrophotometer Shimadzu UV-3600 and Shimadzu UV-2101PC equipped with ISR 240 for measuring the reflection spectra. Absorption spectra in small areas $\left(0.16 \mathrm{~mm}^{2}\right)$ were also recorded using a spectrophotometer diode array of OceanOptics PC2000, during the gradual heating of single crystal samples from room temperature to $430{ }^{\circ} \mathrm{C}$ at a rate of $5{ }^{\circ} \mathrm{C} / \mathrm{min}$ with Linkam LTS420E Thermal Stage.

The microscopic observations were performed with the registration of images using Nikon Eclipse E600 microscope equipped with a camera Nikon TV Lens C- $0.45 \times$. The observations were made during the annealing process of single crystal fragments, isolated from halite type $\mathrm{A}$ and $\mathrm{C}$, during heating from room temperature to $430{ }^{\circ} \mathrm{C}$ at a rate of $10{ }^{\circ} \mathrm{C} / \mathrm{min}$.

All types of halite (A, B, C, D) in the form of single crystal samples were examined by Raman spectroscopy using Renishaw inVia spectrometer and Leica microscope with $50 \times$ magnification objective. The samples were excited with high power near-infrared diode lasers (HP NIR) using excitation at $785 \mathrm{~nm}$ (ca. $15-20 \mathrm{~mW}$ on a sample). Confocal microscope mode allows performing depth profile measurements and also 2-dimensional point-by-point mapping on micrometer scale. The experimental data were worked out using software GRAMS/32 AI ver. 6.0, 1991-2000 Galactic Industries Corporation and WiRE 2.0 service pack 9, Renishaw inVia Raman Microscope, 2002 Renishaw plc.

Decomposition of the experimental spectra was performed using the procedure described below. At first stage the $11,765-40,000 \mathrm{~cm}^{-1}$ range was chosen for UV-vis, and two ranges, $300-100 \mathrm{~cm}^{-1}$ and $3,500-$ $500 \mathrm{~cm}^{-1}$, were considered for Raman spectra. Secondly, the peak positions of components assigned according to the literature were imposed. The band shape of every peak was then fitted as Lorentzian-Gaussian type. And finally the sum of all calculated peak components were drawn to compare the calculated model of spectra with the experimental data.

\section{Results and discussion}

Absorption due to colour centres and bleaching process

The type of colour centres were characterized, using UV-vis spectroscopy in the following way: $F$ centres - according the band at the $23,100-24,000 \mathrm{~cm}^{-1} ; \mathrm{R}_{1}\left(\mathrm{~F}_{3}\right)$ centres - the band in the range of $18,500-19,200 \mathrm{~cm}^{-1}$; $\mathrm{R}_{2}\left(\mathrm{~F}_{3}\right)$ centres - the band in the range of 17,200 $17,700 \mathrm{~cm}^{-1}$; plasmons - the band in the range of $15,900-17,100 \mathrm{~cm}^{-1} ; \mathrm{M}\left(\mathrm{F}_{2}\right)$ centres - the band in the range of $14,200-15,400 \mathrm{~cm}^{-1}$ (Wesełucha-Birczyńska et al. 2012; compare Ivey 1947 and Seinen et al. 1994a). The position of bands varied from sample to

\section{Sample A}
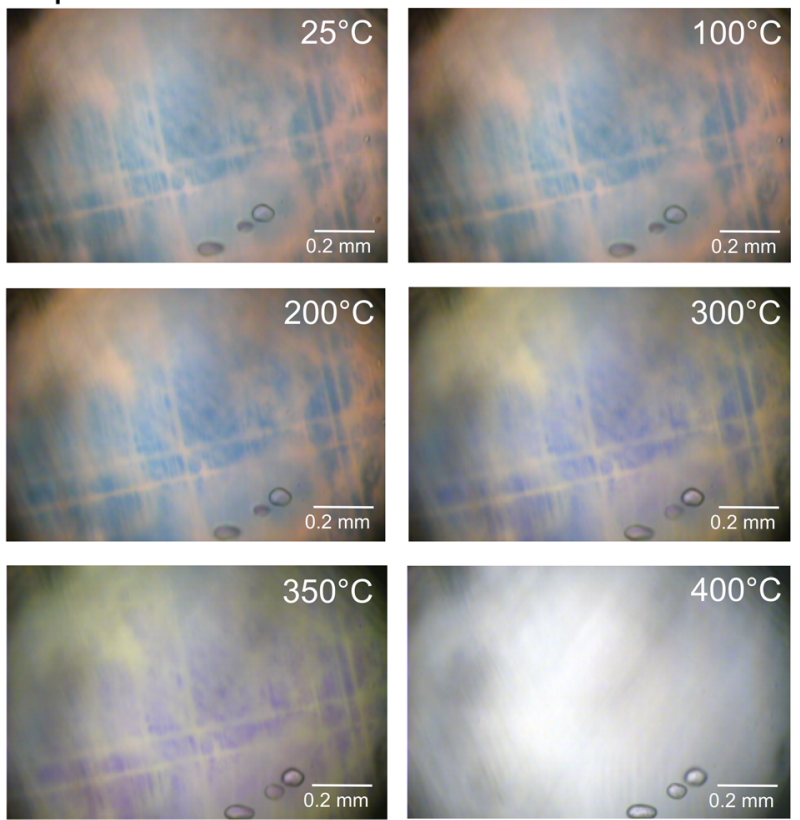

\section{Sample C}
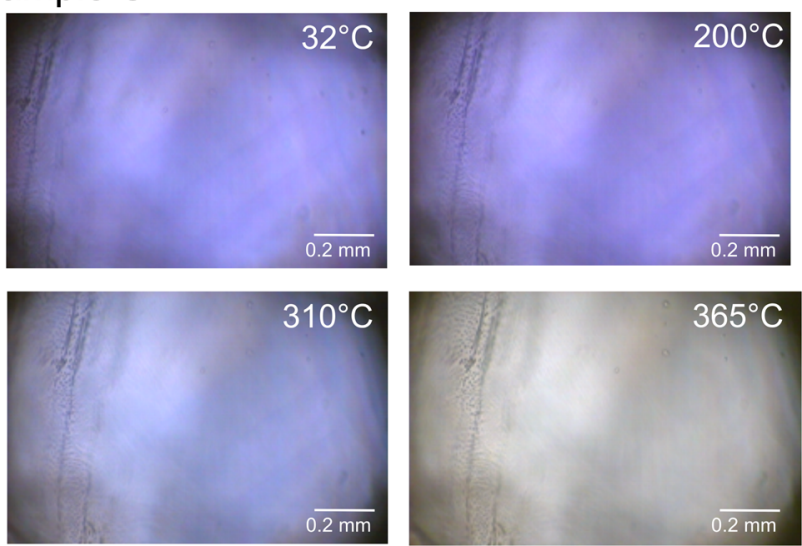

Fig. 2 The colour changes of single crystal fragments of halite A during heating from $25^{\circ} \mathrm{C}$ to $400{ }^{\circ} \mathrm{C}$ and that of $\mathrm{C}$ during heating from $32{ }^{\circ} \mathrm{C}$ to $365^{\circ} \mathrm{C}$ 
sample in relatively narrow range but the set of components was characteristic for the particular type of halite. Estimated standard deviations of band positions were in the range $70-200 \mathrm{~cm}^{-1}$ and those of FWHM: $70-130 \mathrm{~cm}^{-1}$ for well defined maxima. These component bands are shown in Fig. 1. For each of the component bands the population for colour centres, given in Table 1, was evaluated according to Smakula's equation (Smakula 1930). The blue halite crystals undergo bleaching process during heating. The colour changes registered for a single crystal fragment of halite A during heating $\left(25{ }^{\circ} \mathrm{C}\right.$ to $\left.400{ }^{\circ} \mathrm{C}\right)$ and for halite $\mathrm{C}$ $\left(32{ }^{\circ} \mathrm{C}\right.$ to $\left.365^{\circ} \mathrm{C}\right)$ are shown in Fig. 2. The registration of UV-vis spectra along with the bleaching process was used for the interpretation of variability and dynamics of colour centre populations in the function of temperature (Fig. 3 and Fig. 4).

As can be seen in Fig. 4 the population of plasmons are predominated at room temperature for type A samples. However, it decreased with increasing temperature and disappeared at $300{ }^{\circ} \mathrm{C}$, while the population of $\mathrm{R}_{2}\left(\mathrm{~F}_{3}\right)$ centres increased to a maximum at the temperature of $250{ }^{\circ} \mathrm{C}$, and subsequently a gradual band reduction was observed up to a complete disappearance at
$420{ }^{\circ} \mathrm{C}$. With temperature increasing the population of plasmons in type B samples (Fig. 4) decreased from a maximum at $62{ }^{\circ} \mathrm{C}$ concurrently to the population of $\mathrm{R}_{2}\left(\mathrm{~F}_{3}\right)$ centres, which had a maximum at $250{ }^{\circ} \mathrm{C}$. Both populations disappeared at $395{ }^{\circ} \mathrm{C}$. In addition, for those types of halite samples (A and B) the relatively large population of $\mathrm{R}_{1}\left(\mathrm{~F}_{3}\right)$ centres was observed with the maxima at $24{ }^{\circ} \mathrm{C}$ and at $250{ }^{\circ} \mathrm{C}$ for $\mathrm{A}$ and for $\mathrm{B}$, respectively. For $\mathrm{C}$ samples the population of plasmons at $24{ }^{\circ} \mathrm{C}$ was comparable to that observed for type A samples, while the population of $\mathrm{R}_{1}\left(\mathrm{~F}_{3}\right)$ was predominant. With the increasing temperature the population of plasmons achieved a maximum value at $150{ }^{\circ} \mathrm{C}$, and the population of $\mathrm{R}_{1}\left(\mathrm{~F}_{3}\right)$ at $250{ }^{\circ} \mathrm{C}$. Almost complete disappearance of the plasmons and $\mathrm{R}_{1}$ populations was observed at $420{ }^{\circ} \mathrm{C}$. In all types of halite the population of $\mathrm{M}\left(\mathrm{F}_{2}\right)$ centres was very small. It is worth noting that discreet $\mathrm{F}$ centres, in the investigated samples, were found at $23,600-24,000 \mathrm{~cm}^{-1}$, whereas the population of unidentified band at $26,200-26,500 \mathrm{~cm}^{-1}$ was negligible for all samples. Variability and dynamics of colour centre populations in the function of temperature derived from the graphical interpretation of the UV-vis spectra (Fig. 4) are in agreement with the colouration
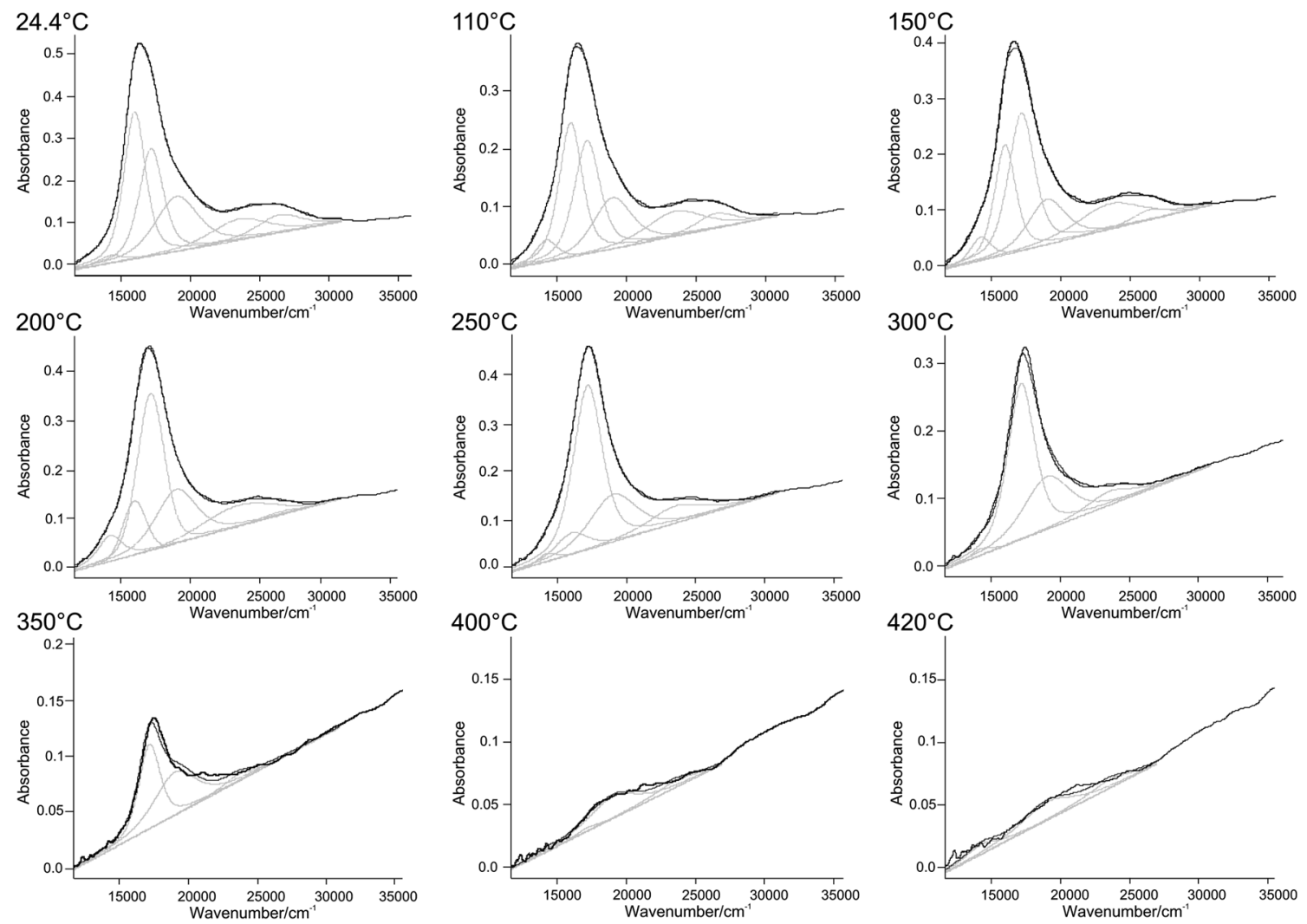

Fig. 3 An example of the variation of the absorption band with increasing temperature for sample A: black line - experimental data, grey lines increased from $25{ }^{\circ} \mathrm{C}$ to $430{ }^{\circ} \mathrm{C}$ during experiment, however the last band components, graphite line - calculated fit. The temperature 
Fig. 4 The variability of the population of colour centres $\mathrm{N}_{\mathrm{F}}$ with the temperature for halite type $\mathbf{a}, \mathbf{b}$ and $\mathbf{c}$. Red colour indicates $\mathrm{F}$ centre band, green $\mathrm{R}_{1}\left(\mathrm{~F}_{3}\right)$ centre band, purple $\mathrm{R}_{2}\left(\mathrm{~F}_{3}\right)$ centre band, yellow colour indicates plasmon band, orange colour indicates $\mathrm{M}\left(\mathrm{F}_{2}\right)$ centre band. The band at the range $26,200-26,500 \mathrm{~cm}^{-1}$ has not been interpreted yet
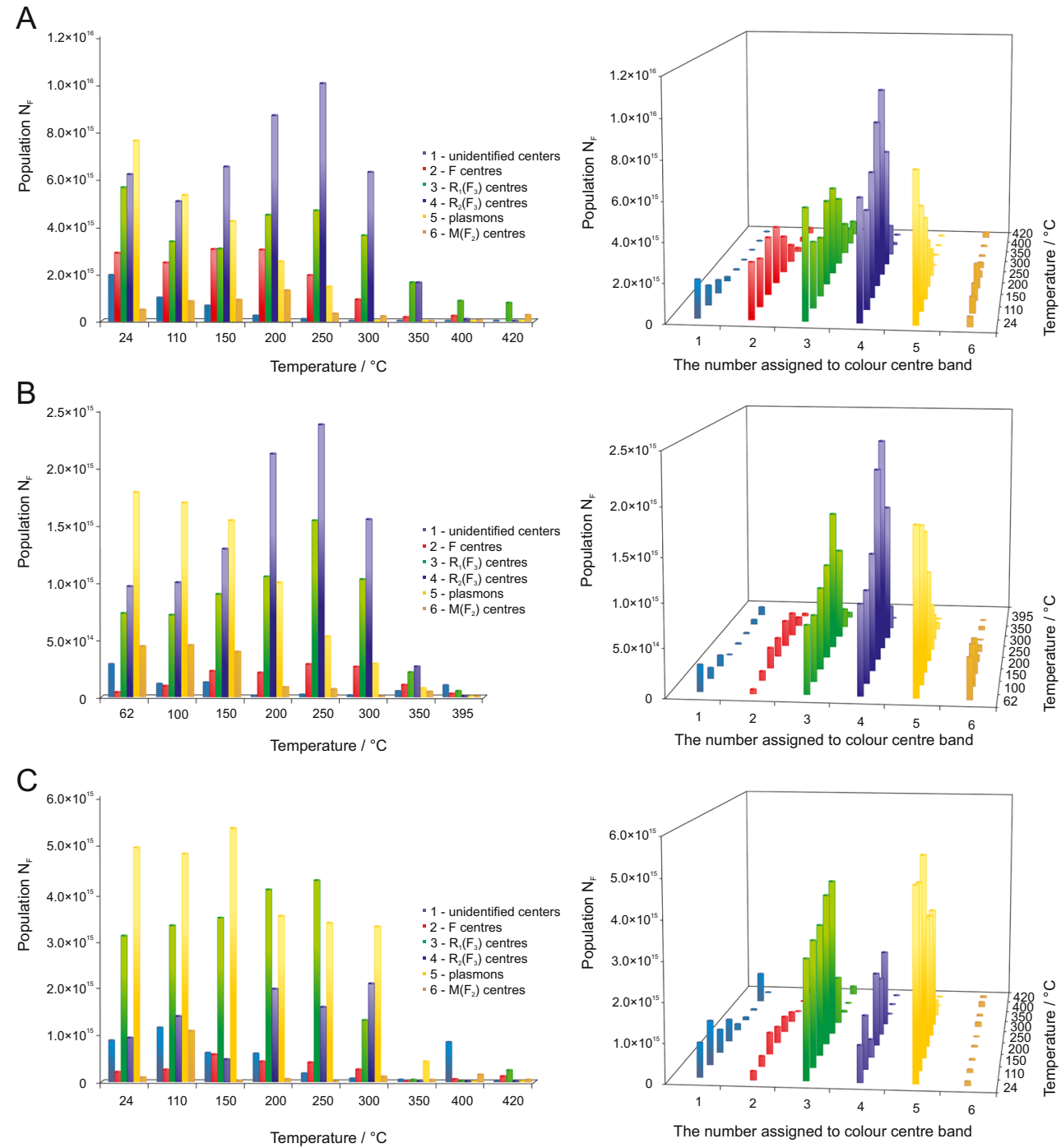

changes observed using optical microscope as colours complementary to light absorption (Fig. 2).

\section{Micro-Raman spectra for colour centres and bleaching} process

In the case of single crystals type A and B, very intense bands in the ranges of 191-193, 217-220, and 251-254 $\mathrm{cm}^{-1}$ as well as a broad band at $c a .2,160 \mathrm{~cm}^{-1}$ were observed (Table 2, Fig. 5). Estimated standard deviations of band positions were ca. $1 \mathrm{~cm}^{-1}$ and those of FWHM ca. $4 \mathrm{~cm}^{-1}$ for well defined maxima. The broad band was also observed for the halite single crystals of type $\mathrm{C}\left(2,180 \mathrm{~cm}^{-1}\right)$ and type D $\left(2,160 \mathrm{~cm}^{-1}\right)$. The bands in the range of the $100-300 \mathrm{~cm}^{-1}$ indicate the presence of the colloidal Na precipitation (Duval et al. 1987). The observed values are within the frequency range of the phonon states in $\mathrm{NaCl}$ with phonon cutoff
Table 2 Bands position $\left(\mathrm{cm}^{-1}\right)$, FWHM $\left(\mathrm{cm}^{-1}\right)$, the intensity of the peaks and the area of the peaks in the micro-Raman spectra for single crystals of Kłodawa halites

\begin{tabular}{llll}
\hline Sample & Band components & Position of maximum & FWHM \\
\hline A & I & 193 & 32 \\
& II & 218 & 31 \\
& III & 251 & 35 \\
& IV & 2,160 & 1,270 \\
B & I & 191 & 33 \\
& II & 220 & 36 \\
& III & 254 & 32 \\
& IV & 2,160 & 1,530 \\
C & IV & 2,180 & 1,620 \\
D & IV & 2,160 & 1,530 \\
\hline
\end{tabular}

Estimated standard deviations of band positions are $c a .1 \mathrm{~cm}^{-1}$ and those of FWHM ca. $4 \mathrm{~cm}^{-1}$ for well defined maxima 
Fig. 5 Micro-Raman spectra for single crystal samples A, B, C and $D$ with the spectrum of recrystallized A sample as inset. Band components are shown separately for two ranges: 300 $100 \mathrm{~cm}^{-1}$ (a) and 3,500-500 $\mathrm{cm}^{-1}$ (b); black line - experimental data, grey lines - band components (enumeration according to Table 2), graphite line - calculated fit. In some cases all curves line up
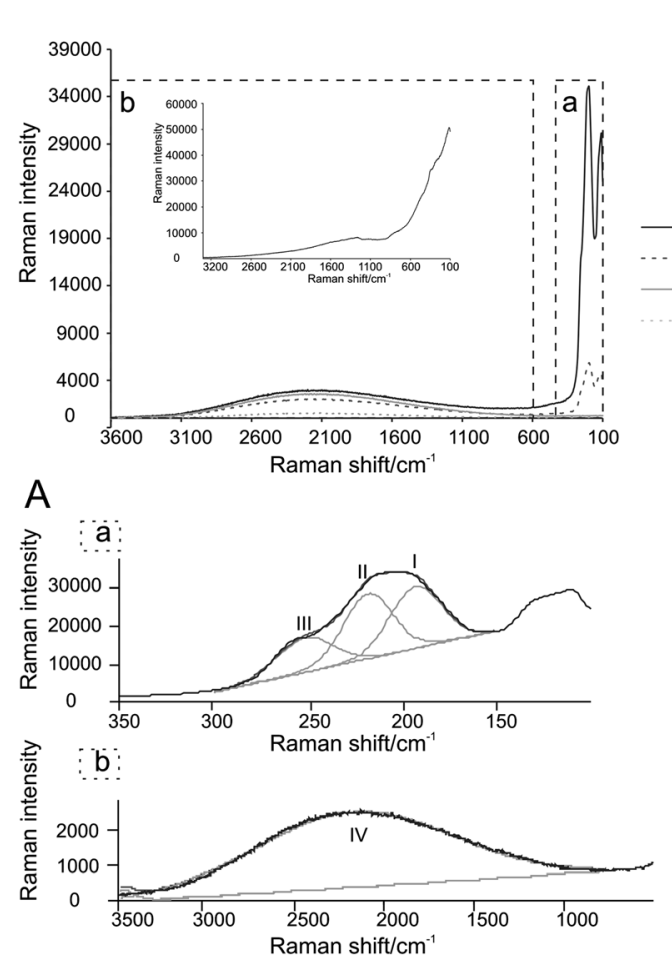
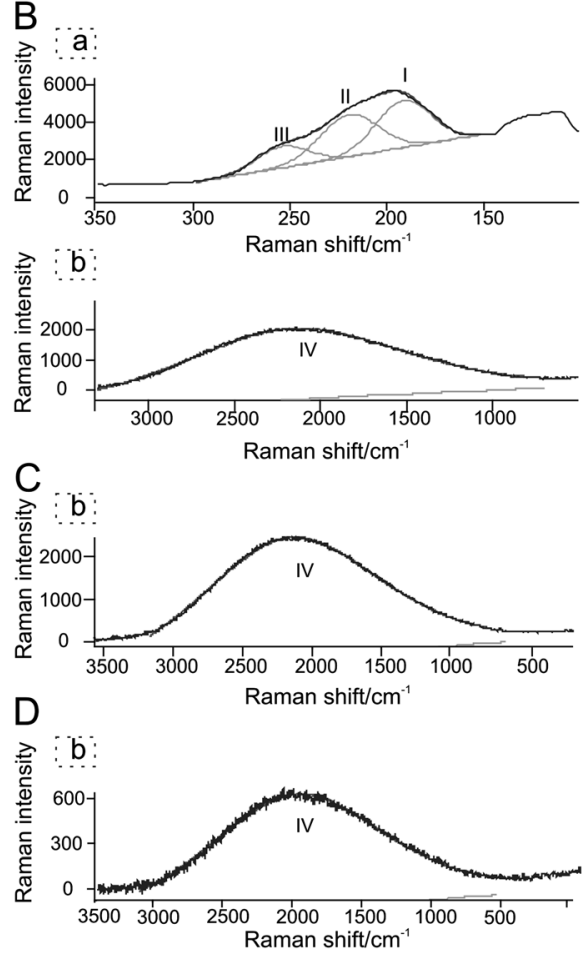

frequency at $260 \mathrm{~cm}^{-1}$. The broad band around 2,160$2,180 \mathrm{~cm}^{-1}$ has not been taken into account in these considerations as it was also observed for colourless halite D. It is possible that in this case discrete $\mathrm{F}$ centres of very small population have gradually aggregated into unspecified clusters. For the recrystallized sample A the spectrum has completely different character - typical for pure $\mathrm{NaCl}$ - what can be seen in the inset of Fig. 5 (note the Rayleigh component).

The micro-Raman spectroscopy was also used to examine the bleaching process. Blue halite single crystal sample (type A) was divided into three fragments which were then
Fig. 6 Variation of micro-Raman spectra for single crystal samples of A type showing bleaching process: at $30^{\circ} \mathrm{C}$ (observed colour of sample was navy blue) and at $285^{\circ} \mathrm{C}$ (the sample was purple). At $410^{\circ} \mathrm{C}$ the sample was colourless and no bands were observed in micro-Raman spectra. Band components are shown for the ranges 300 $100 \mathrm{~cm}^{-1}$ and $3,500-500 \mathrm{~cm}^{-1}$ both at $30^{\circ} \mathrm{C}$ and at $285^{\circ} \mathrm{C}$
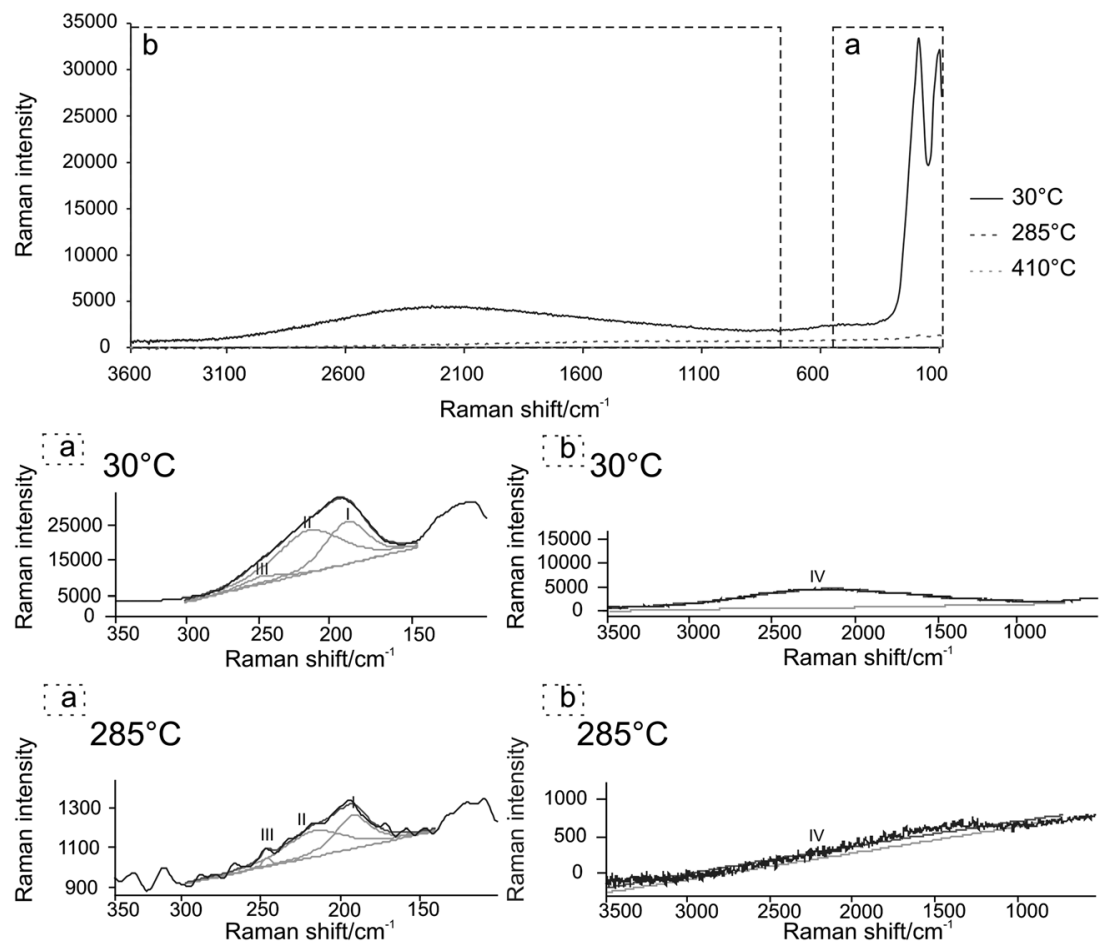
examined independently after heating up to $30{ }^{\circ} \mathrm{C}, 285{ }^{\circ} \mathrm{C}$, and $410^{\circ} \mathrm{C}$, respectively. The obtained micro-Raman spectra were shown in Fig. 6. A complete bleaching was achieved at ca. $400{ }^{\circ} \mathrm{C}$.

\section{Conclusion}

The experiments revealed high dynamics of identified colour centres different for each type of halite samples. In navy blue (A) and pale blue (B) samples the plasmons and $\mathrm{R}_{2}\left(\mathrm{~F}_{3}\right)$ bands were predominated showing maximal populations at different temperatures: $24{ }^{\circ} \mathrm{C}$ and $250{ }^{\circ} \mathrm{C}$, respectively. The blue component of the observed colouration fade away with increasing temperature, as can be seen under optical microscope. This process is due to the reduction of the population of plasmons, leaving exclusively purple component above the $300{ }^{\circ} \mathrm{C}$. The purple sample $(\mathrm{C})$ has the population of plasmons and $\mathrm{R}_{1}\left(\mathrm{~F}_{3}\right)$ similar to those of navy blue $\mathrm{A}$, however it has much lower population of $R_{2}\left(F_{3}\right)$ which is comparable to that in pale blue sample B.

In micro-Raman spectra the bands ca. 191 and $218 \mathrm{~cm}^{-1}$ observed for A and B halites in the $100-300 \mathrm{~cm}^{-1}$ range arose from the colour centres and $\mathrm{Na}$ colloids present in the samples (Sonnenfeld 1995; Worlock and Porto 1965; Henry 1966; Duval et al. 1987). All the samples (A, B, C, and D) had a broad Raman band with the maximum at about $2,100 \mathrm{~cm}^{-1}$ for which F-centre clusters of yet unrevealed structure were responsible. The band at $c a .190 \mathrm{~cm}^{-1}$ was not observed in the recrystallized colourless sample $\mathrm{A}$, and it also disappeared during bleaching process under heating together with the other bands observed in the $100-300 \mathrm{~cm}^{-1}$ range.

Acknowledgments S.Z. thanks Dr. Jarosław Grolik, Faculty of Chemistry, Jagiellonian University, for access to use the Linkam Thermal Stages LTS420E with T95-LinkPad Linkam and Dr. Eng. Tomasz Toboła, Faculty of Geology, Geophysics and Environmental Protection, AGH University of Science and Technology, for making available microscope Nikon Eclipse E600 with a camera Nikon TV Lens C-0.45×.

Authors would like to thank the Editors and the Reviewers for the extremely careful and constructive reviews and for the detailed suggestions for improving our manuscript.

Open Access This article is distributed under the terms of the Creative Commons Attribution License which permits any use, distribution, and reproduction in any medium, provided the original author(s) and the source are credited.

\section{References}

Azua-Bustos A, Urrejola C, Vicuña R (2012) Life at the dry edge: microorganisms of the Atacama Desert. FEBS Lett 586:29392945. doi:10.1016/j.febslet.2012.07.025
Duval E, Mariotto G, Montagna M, Pilla O, Viliani G, Barland M (1987) Low-frequency surface-enhanced raman scattering from fractal vibrational modes localized at the NaCl-Na colloid interface. Europhys Lett 3(3):333-339. doi:10.1209/ 0295-5075/3/3/014

Edwards HG, Mohsin MA, Sadooni FN, Nik Hassan NF, Munshi $T$ (2006) Life in the sabkha: raman spectroscopy of halotrophic extremophiles of relevance to planetary exploration. Anal Bioanal Chem 385(1):46-56. doi:10.1007/s00216006-0396-3

Groote JC, Weerkamp JRW, Seinen J, den Hartog HW (1994) Radiation damage in NaCl. IV Raman Scattering. Phys Rev B 50(14):9798 9802. doi:10.1103/PhysRevB.50.9798

Henry CH (1966) Analysis of raman scattering by F centres. Phys Rev 152(2):699-704. doi:10.1103/PhysRev.152.699

Howard CLH, Kerr PF (1960) Blue halite. Science 132(3443):18861887. doi:10.1002/pssb. 19630030409

Ivey HF (1947) Spectral Location of the Absorption Due to Color Centers in Alkali Halide Crystals. Phys Rev 72:341-343. doi:10.1103/ PhysRev.72.341, 72

Janiów S, Misiek G, Toboła T, Natkaniec-Nowak L (2008) Blue salts in Kłodawa Salt Mine. In: Toboła T, Natkaniec-Nowak L (eds) Blue Halite of the Kłodawa Salt Dome, (in Polish with English summary). AGH University of Science and Technology Press, Kraków, pp 24-53

Natkaniec-Nowak L, Toboła T (2003) Blue salt from Kłodawa, (in polish with English summary). Pol Geol Rev 51(5):435-438

Seinen J, Groote JC, Weerkamp JRW, den Hartog HW (1994a) Radiation damage in $\mathrm{NaCl}$. II The early stage of F-centre aggregation. Phys Rev B 50(14):9787-9792. doi:10.1103/ PhysRevB.50.9787

Seinen J, Weerkamp JRW, Groote JC, den Hartog HW (1994b) Radiation damage in NaCl. III Melting Phenomena of Sodium Colloids. Phys Rev B 50(14):9793-9797. doi:10.1103/ PhysRevB.50.9793

Smakula A (1930) Über erregung und entfärbung lichtelektrisch leitender alkalihalogenide. Z Phys 59(9-10):603-614. doi:10.1007/ BF01344801

Sonnenfeld P (1995) The colour of rock salt - a review. Sediment Geol 94:267-276. doi:10.1016/0037-0738(94)00093-A

Toboła T, Natkaniec-Nowak L, Szybist A, Misiek G, Janiów S (2007) Blue salts in kłodawa salt mine, (in polish with English summary). Mineral Resour Manag IGSMiE PAN 23(1):117-132

Weerkamp JRW, Groote JC, Seinen J, den Hartog HW (1994) Radiation damage in $\mathrm{NaCl}$. I Optical-absorption experiments on heavily irradiated samples. Phys Rev B 50(14):9781-9786. doi:10.1103/ PhysRevB.50.9781

Wesełucha-Birczyńska A, Toboła T, Natkaniec-Nowak L (2008) Raman microscopy of inclusions in blue halites. Vib Spectrosc 48:302-307. doi:10.1016/j.vibspec.2008.05.005

Wesełucha-Birczyńska A, Zelek S, Stadnicka K (2012) Blue halite colour centre aggregates studied by micro Raman spectroscopy and X-ray diffraction. Vib Spectrosc 60:124-128. doi:10.1016/j.vibspec.2011. 11.001

Worlock JM, Porto SPS (1965) Raman scattering by F centres. Phys Rev Lett 15(17):697-699. doi:10.1103/PhysRevLett.15.697

Zelek S (2012) Structural and physical-chemical characteristics of blue halite from Kłodawa Salt Mine and embedded solid inclusions (In Polish with English summary). Dissertation, Jagiellonian University, Kraków, Digital Document ID: DOKT_2012_172

Zelek SM, Stadnicka KM, Toboła T, Natkaniec-Nowak L (2014) Lattice deformation of blue halite from zechstein evaporite basin: kłodawa salt mine, Central Poland. Miner Petrol. doi:10.1007/s00710-0140323-9 